\title{
A COERÊNCIA SEGUNDO A PERSPECTIVA DA TEORIA DA LINGUAGEM DE EUGENIO COSERIU
}

\section{COHERENCE FROM THE PERSPECTIVE OF EUGENIO COSERIU'S LANGUAGE THEORY}

Clemilton Lopes Pinheiro $^{1 *}$

Jéssica Santos de Oliveira ${ }^{* *}$

\begin{abstract}
RESUMO
Em trabalhos já historicamente reconhecidos na Linguística Textual, a coerência, de forma geral, tem sido concebida como mensagem ou conteúdo do texto, ou ainda como uma rede de relações conceituais que se estabelecem na tessitura textual. Neste trabalho, a partir da teoria da linguagem de Eugenio Coseriu na qual ele propõe a existência de três níveis da linguagem (universal, histórico e textual), revemos os traços (nem sempre conciliáveis) imputados à coerência. Nosso objetivo é, assim, apresentar uma proposta de compreensão da coerência com base na teoria dos níveis da linguagem. Como conclusão, consideramos que a coerência não é um fenômeno único e homogêneo. Trata-se, ao contrário, de um fenômeno tripartido do qual emergem três objetos teóricos, cada um deles alinhado a um nível da linguagem.
\end{abstract}

PALAVRAS-CHAVE: Coerência textual; Níveis da linguagem; Teoria coseriana

\begin{abstract}
In works historically recognized in Textual Linguistics, coherence, in general, has been conceived as a message or content of the text, or as a network of conceptual relations established in the textual texture. In this paper, from Eugenio Coseriu's theory of language in which he proposes the existence of three levels of language (universal, historical and textual, we review the multiplicity of imputed (not always reconcilable) features to coherence. We aim to present a proposal for understanding coherence based on the theory of language levels, unraveling the relationship between the concepts of coherence, meaning and sense. As a result, we consider that coherence is not a single and homogeneous phenomenon. On the contrary, coherence is a tripartite phenomenon from which three theoretical objects emerge each of them aligned to a level of language.
\end{abstract}

KEYWORDS: Coserian theory; Levels of language; Textual coherence

\section{INTRODUÇÃO}

A teoria da linguagem de Eugenio Coseriu se baseia na premissa de que o ser humano possui um saber múltiplo, que abrange três níveis: o universal, o histórico e o textual (COSERIU, 2007). Isso significa dizer que, além do saber mais facilmente perceptível, que é o saber falar uma língua, possuímos também o saber falar em geral e o saber configurado nos textos. O nível histórico é o nível das línguas, consiste na capacidade de podermos falar um

\footnotetext{
* Professor de Linguística, Departamento de Letras, Programa de Pós-Graduação em Estudos da Linguagem, Universidade Federal do Rio Grande do Norte. E-mail: clemiltonpinheiro@hotmail.com

** Professora de Português na Educação Básica, Mestre em Estudos da Linguagem, Programa de PósGraduação em Estudos da Linguagem, Universidade Federal do Rio Grande do Norte. E-mail: je.sanoli@gmail.com
} 
determinado idioma, como o português ou o francês; o nível universal abrange os princípios gerais do expressar-se, independentemente da língua empregada; e o nível textual engloba a capacidade de compreender e construir os sentidos do texto em uma situação específica.

A partir dessa proposta teórica, é possível conceber que os estudos da linguagem podem abranger também esses três níveis. Ainda que não haja essa consciência por parte dos linguistas, para Coseriu, os estudos linguísticos necessariamente abordam uma dessas dimensões da linguagem. Dessa forma, o autor propõe distinções a fim de elucidar tal problemática: além da Linguística das línguas, já bem conhecida, haveria também uma Linguística do falar e uma Linguística do texto. Para ele, essas distinções possibilitam que objetos referentes a níveis distintos da linguagem sejam tratados dentro das especificidades de cada nível, evitando confusões teóricas.

Fundamentando-nos nessa proposta, entendemos que os estudos da coerência, e o próprio conceito de coerência, muito revisitado ao longo da história dos estudos linguísticos, podem ser realinhados com base nos três níveis da linguagem. O objetivo deste trabalho é, portanto, propor um realinhamento das perspectivas de compreensão da coerência a partir da teoria da linguagem de Eugenio Coseriu. Apesar de Coseriu não se deter no estudo específico da coerência, partindo de sua teoria, podemos realizar uma proposta conceitual sobre a coerência, situando-a nos níveis universal, histórico e individual.

Para atingir esse objetivo, revisitamos alguns dos principais trabalhos sobre coerência: Bellert (1970), Halliday e Hasan (1976), Beaugrande e Dressler (1981; 1997), Charolles (1978), Bernardez (1982; 2003), Araújo (2002), Marcuschi (2001), Koch e Travaglia $(1989)^{2}$. Detectamos, nesse conjunto de trabalhos, duas concepções de coerência: a) processo de construção de sentido, resultado da estruturação linguística do texto, e b) unidade conceitual do texto. Vimos que, nesses casos, apesar de falarem sempre de coerência, nem sempre os autores estão tratando de um mesmo fenômeno, porque tomam como ponto de partida critérios diferentes. Relacionamos, então, esses critérios às especificidades de cada um dos três níveis de modo que a complexidade do fenômeno seja considerada a partir de um mesmo critério.

\section{A teoria dos níveis da linguagem de Eugenio Coseriu}

A teoria dos níveis da linguagem teve seus primeiros fundamentos erguidos por Eugenio Coseriu já nos anos 50, época em que lecionou na Universidade da República, em Montevidéu, Uruguai. Esse período foi, de acordo com Kabatek (2017, p. 1), "sua época mais produtiva e mais prodigiosa: é aqui onde desenvolve o edifício fundamental de seu pensamento". Obras de destaque foram escritas nessa época. A essa altura, o linguista romeno já esboçava os fundamentos da teoria que concebe a linguagem em três níveis:

O falar é uma atividade universal que se realiza por indivíduos particulares, enquanto membros de comunidades históricas. Portanto, [o falar] pode considerar-se em sentido universal, em sentido particular e em sentido histórico (COSERIU, 195556 , p.31, grifos do autor).

A ideia de que a linguagem possui três níveis pode ser explicada, em suma, pelo entendimento coseriano de que a linguagem constantemente cria e atualiza conteúdos não apenas por uma única via de efetivação. Há, dessa forma, um funcionamento simultâneo da linguagem em três dimensões ou níveis: universal, histórico e individual. Em todos esses níveis, produzimos conteúdos de linguagem próprios, de natureza distinta (COSERIU, 1984).

2 Oliveira (2020) apresenta uma resenha detalhada desses trabalhos. 
O nível universal diz respeito aos fenômenos comuns a todas as línguas. A primeira propriedade universal das línguas é seu caráter sígnico, ou seja, a possibilidade de referir-se a algo que não se identifica com ela mesma. A comparação entre as línguas fornece uma evidência para essa propriedade: diferentes línguas correspondem a configurações distintas para uma mesma realidade extralinguística. Algumas atividades relacionadas à linguagem, como a tradução, por exemplo, só são possíveis a partir do pressuposto de que diferentes línguas podem referir-se a uma mesma realidade e o fazem de forma diferenciada. A segunda propriedade atribuída ao nível universal da linguagem é a faculdade universal de falar, não determinada historicamente. "Trata-se de um saber falar que não coincide simplesmente com o saber falar alemão, francês etc., mas que vale para toda língua e para todo falar" (COSERIU, 2007, p. 131).

Ao nível universal cabe a função de designar, com a qual fazemos referência ao extralinguístico, o que de fato todas as línguas realizam. Conforme o autor, existe um risco de não notarmos "a relação da linguagem com o extralinguístico e de esquecer o fato importante de que a linguagem, apesar da sua autonomia, é precisamente uma forma de conhecimento da 'realidade' extralinguística" (COSERIU, 1987, p. 20). Desse modo, ainda que a linguagem vá além da função de designar, ela necessariamente inclui essa tarefa. $O$ conteúdo desse nível, portanto, é aquele com o qual nos referimos a uma coisa do mundo (a designação). No funcionamento da linguagem, com intuito de criar esse conteúdo, o ser humano possui um saber: trata-se do saber elocucional, ou seja, o saber falar em geral.

Esse saber falar em geral também pode ser tratado em termos de uma competência elocucional. Assim como os demais saberes de cada nível, o saber falar em geral está submetido a um julgamento de suficiência. De fato, no falar, sempre avaliamos se o saber é exercido no ato linguístico de maneira satisfatória, ou seja, se a competência elocucional está sendo posta em funcionamento de modo a atender ao esperado.

No nível universal, tal avaliação se refere "ao fato de saber se o falar corresponde em cada caso às expectativas normais [dos falantes]" (COSERIU, 1992, p. 94). Ao falar que atende a tais expectativas gerais chamamos congruente. A congruência é uma avalição feita justamente com base no atendimento ou não aos princípios gerais do pensar e ao alinhamento ou desalinhamento com o conhecimento das coisas. Efetivamente, ambas as categorias estão acima das diferenças idiomáticas. Dessa forma, esse julgamento se aplica somente ao saber elocucional. O linguista romeno exemplifica tal fato com o exemplo: "Os cinco continentes são quatro: Europa, Ásia e África” (COSERIU, 1992, p.107).

Essa afirmação evidencia que o plano universal engloba aspectos linguageiros que se sobrepujam às especificidades das línguas, pois a incongruência desse exemplo não pode ser justificada linguisticamente, posto que independentemente do idioma empregado o ouvinte ainda identifica uma anormalidade. Se alguém fala, por exemplo, a mesma coisa em francês, inglês ou em algum outro idioma o impasse permanece, porque há problemas de conformidade ao critério da congruência, que é o parâmetro valorativo do nível universal da linguagem.

O plano universal da linguagem é, dessa forma, o plano em que ocorrem os fenômenos comuns a todas as línguas, isto é, tangentes a todo falar. Esses fenômenos se fundamentam nesses dois traços basilares - ora expostos - comuns a todos os idiomas: o fato de que a linguagem pode se referir a algo que não pertence a ela mesma, ou seja, pode se referir ao extralinguístico; e a fundamentação comum a todos os idiomas no saber falar em geral.

Cada língua particular dispõe de um léxico estruturado de forma diferente, possui sua própria gramática e seu sistema fonológico. Constitui-se, no caso, o nível histórico, que compreende, portanto, uma língua concreta e seus processos de significação. O nível histórico da linguagem possui a função de significar, que produz como conteúdo o 
significado. Essa função é a responsável pela organização da realidade extralinguística numa língua. Cabe perceber, então, que tal organização é feita de modo distinto por cada língua, de forma que o significado existe dentro de cada técnica histórica de falar e corresponde ao que efetivamente se diz em dado idioma. O significado é, desse modo, o conteúdo de uma língua específica.

Em relação a esse nível da linguagem também é importante ressaltar que as línguas não são sistemas unitários e homogêneos, mas apresentam variações diversas, sejam de ordem fonética, lexical, sintática. Efetivamente, "uma língua nunca é um único sistema, mas um entrelaçamento de - em parte - diferentes sistemas" (COSERIU, 1992, p. 37).

O julgamento de conformidade desse nível, que avalia se em um ato linguístico houve a competência idiomática necessária, é a correção. Será analisado, no caso, se a realização linguística é correta ou incorreta, o que sempre dependerá de cada idioma.

O terceiro nível, o individual, diz respeito ao plano do conteúdo próprio e exclusivo do texto. Para sustentar a autonomia do nível dos textos em relação ao nível universal e histórico, Coseriu (2007) assinala, principalmente, o fato de que as regras da língua podem ser suspensas no texto sem provocar rejeição, e de que os textos são influenciados pelos universos de discurso - o que não acontece com as línguas - e têm tradições particulares, diferentes das tradições das línguas históricas.

O conteúdo próprio do nível individual da linguagem é o sentido. O autor concebe sentido como "o conjunto das funções textuais, do que se entende no texto e só no texto" (COSERIU, 2007, p.53). Trata-se de conteúdos exclusivamente do texto, que não são apreendidos universalmente, tampouco historicamente, mas apenas em nível individual. Em suma, o sentido se distingue do significado e da designação, porque não encontra explicação na língua, mas apenas no texto, contando para isso com a consideração de fatores próprios do nível individual da linguagem.

No que diz respeito ao julgamento da conformidade ou não do saber expressivo, fazse uso do critério da adequação. "No nível do texto, o que corresponde a saber expressivo é a adequação: algo pode ser adequado ou inadequado com inteira independência de que seja correto ou incorreto" (COSERIU, 2007, p. 145, grifos do autor).

Nas palavras coserianas, por haver "saberes de conteúdos diferentes e com valores também diferentes é necessário que haja paralelamente três Linguísticas diferentes que os estudem" (COSERIU, 1984, p. 45). É fulcral voltar a destacar que, segundo a teoria coseriana, o ato linguístico deve ser submetido sempre a distintos julgamentos de suficiência, cada qual em sintonia com a natureza do saber que avalia. Essa avaliação é realizada pela Linguística que cabe a cada nível da linguagem, possibilitando que fatos de linguagem: a) do nível universal sejam analisados, como atividade de falar em geral, por sua congruência; b) do nível histórico, enquanto língua, sejam vistos a partir da correção; c) do nível individual, como texto, sejam observados em termos de adequação.

O quadro 01 apresenta um resumo da perspectiva coseriana de linguagem.

Quadro 1 - Os níveis da linguagem e as Linguísticas.

\begin{tabular}{|l|l|l|l|l|l|}
\hline Nível & Saber & Atividade & Conteúdo & Avaliação & Linguística \\
\hline Universal & Elocucional & $\begin{array}{l}\text { Falar em } \\
\text { geral }\end{array}$ & Designação & Congruência & Do falar \\
\hline Histórico & Idiomático & $\begin{array}{l}\text { Falar } \\
\text { uma } \\
\text { língua } \\
\text { concreta }\end{array}$ & Significado & Correção & Das línguas \\
\hline Individual & Expressivo & $\begin{array}{l}\text { Falar } \\
\text { textos }\end{array}$ & Sentido & Adequação & $\begin{array}{l}\text { do Texto/ } \\
\text { Sentido }\end{array}$ \\
\hline
\end{tabular}


Fonte: Elaboração dos autores, com base em Coseriu (1992) e Coseriu (2007)

\section{A coerência e os níveis da linguagem}

Ao revisitarmos alguns dos principais estudos sobre a coerência, pudemos constatar que eles exploram diferentes dimensões do fenômeno tais como as relações conceituais que se estabelecem no texto e o conteúdo transmitido. Em conformidade com o que diz Coseriu (2007, p. 88), pensamos que esses estudos abordam algum dos níveis da linguagem, ainda que não o façam explicitamente e conscientemente: "a divisão da linguagem em três níveis deve realizar-se em todos os âmbitos da linguística, que é importante e iniludível em cada um deles, e que toda disciplina linguística a pressupõe explícita ou tacitamente”.

Desse modo, propomos olhar para a coerência como um arquifenômeno que se realiza e funciona simultaneamente de forma tripartida de acordo com os três níveis da linguagem. O quadro 2 ilustra nossa percepção de que os diferentes aspectos da coerência se alinham a esses níveis.

Quadro 2 - Concepção de coerência como arquifenômeno

\begin{tabular}{|l|c|c|c|}
\hline Nível da linguagem & Universal & Histórico & Individual \\
\hline Coerência & Dimensão & Dimensão & Dimensão \\
& relacionada aos & relacionada à & relacionada à \\
& princípios gerais do & configuração & situação discursiva: \\
pensar e ao & específica de uma & coerência do \\
& conhecimento das & língua: coerência do & sentido \\
& coisas: coerência da & significado & \\
& designação & & \\
\hline
\end{tabular}

Fonte: Elaboração dos autores

\subsection{A coerência no nível universal}

Os princípios gerais do pensar são aqueles que regem o pensamento humano, portanto, são empregados naturalmente no falar. Coseriu (2007) fala especificamente sobre dois deles - ainda que mencione haver outros: a não contradição e a identidade. O primeiro consiste no fato de que que, no falar, não se contradiz o que já foi dito. O segundo refere-se a uma relação de identidade entre o que se fala e o que já foi falado. Por sua vez, o conhecimento das coisas é o conhecimento que temos da realidade do mundo, que é acessado, porque pertencemos à humanidade e temos noções da realidade extralinguística. $\mathrm{O}$ falar é coerente (congruente) na medida em que se realiza com base nesses princípios e nesse conhecimento. Ao contrário, se não há essa base, tem-se o falar incoerente (incongruência).

A perspectiva de coerência que a concebe como rede de relações e conceitos se alinha a essa perspectiva. Os trabalhos que seguem essa direção centralizam a obediência aos princípios do pensar e o embasamento no conhecimento das coisas como definidores da coerência. Se as conexões conceituais de um ato linguístico apresentam inconsistências, violando o princípio da identidade, por exemplo, prejudica-se a coerência no nível universal da linguagem. Como aponta Coseriu, (2007, p. 48), o falar congruente "será um falar claro, consequente e conexo, sobretudo no que se refere aos princípios gerais do pensar [...] e se fundará no conhecimento das coisas".

Bellert (1970), uma das pioneiras na Linguística Textual a tratar sobre a coerência por exemplo, afirma que existem regras gerais do raciocínio que atuam na relação entre os estados de coisas descritos por enunciados sucessivos. Isso ocorreria por meio do conhecimento de mundos associados, isto é, dos mundos admitidos como base para os atos linguísticos em 
questão. Para a autora, o elo de coerência é construído nessa dinâmica entre as regras gerais do raciocínio e o conhecimento de mundos associados.

Outro trabalho que pode ser colocado nessa mesma esteira é o de Charolles (1978). $\mathrm{O}$ autor explora o funcionamento de quatro metarregras, as quais, de acordo com ele, regulam a coerência. Essas metarregras nada mais são que princípios do falar em geral. A metarregra da repetição, por exemplo, é uma das formas assumida pelo princípio da identidade. Conforme já explicado, trata-se de um dos princípios que regem o pensar, e consiste na necessidade de uma relação de identidade entre o que se diz e o que já foi dito. A repetição só pode ocorrer mediante esse princípio do pensar. Cabe salientar que Charolles (1978) lembra que Bellert (1970) é a primeira a anunciar a repetição como uma condição para a coerência.

A metarregra da progressão de Charroles (1978) também se assenta nos princípios gerais do pensar. Como vimos, a repetição se embasa na exigência de que haja elementos de recorrência estrita no falar. A progressão é a contraparte dessa exigência, pois aponta a necessidade de que haja a renovação constante do dito, de modo a acrescentar novas contribuições semânticas em seu desenvolvimento. Por vezes, os autores podem se referir à progressão como "não repetição", mas a percepção que apresentam não é a de negar a repetição como necessária à coerência, mas a de salientar a indispensabilidade de que o falar "para ser coerente [...] não pode simplesmente repetir indefinidamente seu próprio assunto" (CHAROLLES, 1978, p. 58).

Essa percepção é notada por Coseriu (2007, p. 144), quando ele aborda os princípios gerais do falar, que constituem o saber elocucional. Para ele, esse saber é "integrado pelo conhecimento do mundo e das coisas, os princípios gerais do pensar humano, a exigência de clareza e de não repetição". Ou seja, dentre os exemplos que o autor ressalta como princípios gerais do falar está o princípio da progressão (chamada de não repetição).

Ao analisar exemplos de textos de estudantes, como em 01, Charroles (1978, p. 59) chama a atenção para o que ele chama de circulação do discurso, que consiste em uma desproporção entre a contribuição informativa e a repetição. Um estado, ação, objeto ou circunstância pode ser retomado repetida e desnecessariamente. No caso do exemplo, a ponta da picareta e a informação sobre sua forma são repetidos por diversas vezes sem que seja identificada uma razão plausível para tal. Da mesma forma, a informação quanto à ação (bater sobre a ponta da picareta) é repetida logo após ter sido exposta no período anterior. Sendo assim, afeta-se a coerência do falar.

(01)

O ferreiro está vestido com uma calça preta e um chapéu claro e com um paletó cinza e marrom escuro. Tem na mão a ponta da picareta e bate em cima com um martelo, sobre a ponta da picareta. Os gestos que fez, tem a ponta da picareta, e com seu martelo bate sobre a ponta da picareta. A ponta desta ferramenta que se chama a ponta da picareta é pontuda e a outra ponta é quadrada. Para tornar ela vermelha com a ponta da picareta colocou ela no fogo e as mãos estão vermelhas.

O que, de fato, está em análise, nesse caso, é a coerência do falar em geral. Se podemos falar de coerência do texto, isso é possível, porque os textos são observados como meio viável e concreto de estudar linguagem. Portanto, o que fazemos é analisar regras gerais do pensar, que só podem ser vistas nos textos. A esse respeito, Coseriu (2007, p. 121) ressalta o seguinte:

Ainda que se pense que na descrição não se está fazendo outra coisa que explicitar o próprio saber, na realidade se parte de textos, que são o produto de uma espécie 
de fala interior, ou seja, analisam-se textos produzidos nessa fala interior de acordo com as regras que se pretende descrever.

Consideramos que Koch e Travaglia (1989, p. 9) também tecem considerações alinhadas à concepção de coerência no nível universal da linguagem. Eles afirmam:

\begin{abstract}
Certamente, em comentários sobre textos, você já ouviu ou disse coisas como: "Este texto é incoerente", "Falta coerência nas ideias". Quase sempre, tais comentários se ligavam a questões de raciocínio lógico, a contradições entre uma passagem e outra do texto ou entre o texto e o conhecimento estabelecido das coisas. Isto evidencia que o juízo de incoerência não depende apenas do modo como se combinam elementos linguísticos no texto, mas também de conhecimentos prévios sobre o mundo e do tipo de mundo em que o texto se insere.
\end{abstract}

O que esses autores afirmam não é outra questão senão o conhecimento das coisas. Esse tipo de conhecimento, a respeito do funcionamento e estado do mundo, ou do mundo textual admitido, não se confunde com os conhecimentos individuais de um sujeito quanto a fatos não universais, ou seja, os conhecimentos referentes ao nível individual.

\title{
2.2 A coerência no nível histórico
}

Quando uma particularidade da constituição linguística afeta diretamente o significado de um ato linguístico, queremos dizer que, aí, há uma questão de coerência no nível histórico. Muitos dos trabalhos sobre coerência que revisitamos fazem alusão a recursos linguísticos comuns às línguas como parte integrante do processo de construção da coerência. Segundo Koch e Travaglia (1989), por exemplo, a coerência é a possibilidade que o texto tem de fazer sentido, ou seja, a possibilidade de transformar uma sequência linguística em texto. Para tanto, atua uma série de fatores entre eles o conhecimento linguístico, relativo aos mecanismos próprios de uma língua.

O que Bernardez (1982) chama de coerência sintática se encaixa também nessa percepção. A estruturação linguística adequada de um determinado ato linguístico, segundo esse autor, apesar de não ser suficiente para determinar se há coerência, contribui para tal avaliação. Efetivamente, essa percepção de Bernardez (1982, p. 161) tem base na sua defesa de que "não é possível estabelecer uma diferença taxativa entre pragmática, semântica e sintaxe no processo de coerência textual".

No entanto cabe destacar que os chamados mecanismos linguísticos de coerência (ou de coesão, como alguns chamam) são comuns a todas as línguas, apenas são realizados de acordo com o que cada língua dispõe. Assim, a determinação, por exemplo, é universal, mas cada língua tem seus componentes específicos para realizá-la, como o artigo, em português. Da mesma forma, a coordenação é um mecanismo universal, porém no nível histórico, cada língua possui seus próprios conectores coordenativos. E, nessa direção, poderíamos enumerar vários outros exemplos. Trazemos isso para dizer que, se queremos falar de coerência, no nível histórico, há que se ir além do que é comum às línguas, adentrando no que, de um modo particular a um dado idioma, diz respeito ao significado do ato linguístico. A coerência, no nível histórico, diz respeito, portanto, à mobilização do que funciona ou não em uma língua na produção de significado.

Esse tipo de coerência própria do nível histórico pode ser explicado a partir de um exemplo de Coseriu (2007, p. 24) sobre a afirmação e a negação no russo.

O russo tem somente duas partículas de negação e afirmação fundamentais: respectivamente, niete $d a$; mas esta última não significa exclusivamente "sim", mas 
"de acordo com o dito", de modo que se foi perguntado afirmativamente e se está de acordo, o afirmativo é $d a$, mas se foi perguntado negativamente e se está de acordo, também se emprega $d a$.

De fato, na ausência ou insuficiência do saber histórico, um indivíduo poderá não mobilizar a regra idiomática indispensável para responder corretamente a uma simples pergunta fechada em russo, que requer apenas a negação ou afirmação com uma palavra. Ao que intencionava responder com uma concordância à pergunta negativa - por exemplo, "você não quer água?" - usará o "niet", pensando que assim está confirmando sua recusa. Na realidade, porém, tal resposta não cumpre a função da língua, pois a palavra que se espera para negar, nesse caso específico, é "da". Nesse caso, realiza-se um ato linguístico incorreto. Vemos, assim, que o problema em questão tange à coerência no nível histórico, nível da língua.

O objeto nulo $(\mathrm{ON})$ é um fenômeno que ocorre no português brasileiro e em algumas poucas línguas sem proximidade com este idioma, como o chinês e o japonês. Ele diz respeito à possibilidade de o objeto de uma construção transitiva ser omitido em vista de sua recuperação pelo contexto de comunicação. Como isso não ocorre nas línguas germânicas ou mesmo em outras línguas românicas, como o espanhol, abre-se um espaço para que incorreções sejam geradas. Uma frase com $\mathrm{ON}$ em uma língua que não permite esse tipo de construção constitui, portanto, uma incorreção. Vejamos o que diz Jansen (2016, p. 15) sobre alguns estudos desse fenômeno.

\begin{abstract}
Quando o ON é empregado, fica assim um "buraco" na frase, nos ouvidos e olhos de falantes de línguas germânicas e também de outras línguas românicas; já que o normal nessas línguas é marcar a transitividade com um pronome, quando não há outro objeto direto na frase, e deixar de fazer isso é normalmente considerado agramatical. Por exemplo, as duas frases seguintes foram apresentadas a vários falantes nativos das várias línguas românicas, na própria língua de cada um: “Aos 19 anos ganhei a chave de casa. Eu contei _ para todo mundo". Todos queriam encher o espaço vazio com um pronome clítico da respetiva língua, exceto os falantes nativos do português brasileiro (PB).
\end{abstract}

\title{
2.3 A coerência no nível individual
}

Um ponto comum entre parte considerável entre os que estudam a coerência é a consideração de que o sentido é próprio da textualidade. Nesse caso, a coerência é estudada sob um ponto de vista que vê o texto como nível autônomo da linguagem, atentando para o que é propriamente textual: o sentido. Isso alinha-se ao nível individual da linguagem. Os trabalhos que partem dessa abordagem para estudar a coerência estão, de fato, situando-a no nível individual, porque a focalizam no que há de especificamente textual.

Obras tais quais como a de Beaugrande e Dressler (1981; 1997), uma das primeiras a explorar o conceito de coerência, concebendo-a com um dos chamados fatores de textualidade, apresentam a coerência como propriedade de um acontecimento particular aos sujeitos. Para eles, a compreensão do fenômeno da coerência potencialmente serve para perfilar melhor os traços que seriam próprios a uma ciência do texto cujo fundamento é a ideia de que o texto é uma atividade. Ao apontarem os pilares do que deveria ser a ciência do texto, esses autores precedem a esteira de Coseriu (2007) segundo o qual o texto corresponde a um nível autônomo da linguagem, o nível individual, que deve ser investigado por uma legítima Linguística de Texto.

Nessa mesma esteira, Koch (2009, p. 30) indaga qual é, afinal, a propriedade definidora do texto e responde: "um texto se constitui enquanto tal no momento em que os parceiros de uma atividade comunicativa global [...] são capazes de construir, para ela, 
determinado sentido". Em outras palavras, o que leva um interlocutor a identificar um texto como tal é a coerência no nível individual, a qual é compreendida como a construção de um conteúdo textual-discursivo: o sentido.

Concebida desse modo, a coerência é susceptível a fatores da ordem do individual, e se estabelece com base em conhecimentos de mundo dos sujeitos. Nesse sentido, destacamos a citação de Bernardez (2003, p. 13).

Se coerência é uma coisa que "está no" texto, algo que o caracteriza como objeto, não poderia ser distinta segundo os receptores - como de fato sabemos que ocorre [...] de modo que talvez o que tenhamos que fazer é mudar nossa definição.

Conforme o autor, o fato em si de a coerência ser distinta de acordo com o interlocutor, numa dada situação, mostra que ela só se dá no ato individual de linguagem na produção e recepção de um dado texto. Ele afirma ainda: "a coerência só existe em termos de seu encaixe no mundo conceitual do receptor" (BERNARDEZ, 2003, p.14). Isso não faz que o caráter relativamente estável dos conteúdos textuais, fato outrora comentado por Beaugrande e Dressler (1997), deixe de existir. Pensamos que, na realidade, ocorre uma conjunção entre a dependência do interlocutor na tarefa interpretativa e a estabilidade de sentido do próprio texto. Dessa forma, ainda que haja uma influência do mundo conceitual do indivíduo, defendemos juntamente a Coseriu (2007) que o sentido textual possui certa objetividade, e que "essa objetivação pode ser verificada através dos procedimentos textuais" (PINHEIRO e MOREIRA, 2018, p.14), que atuam de modo particular em cada texto.

Assim, do ponto de vista do nível individual da linguagem, a construção da coerência se dá sempre no texto concreto, em dependência dos interlocutores, mas igualmente subordinada às possibilidades conferidas pelo texto em sua objetivação do sentido. Tal objetivação não desmerece a noção de individualidade, pois, na teoria coseriana, o individual da linguagem remete à configuração única de cada texto no que tange aos procedimentos de construção de sentido. Conforme Pinheiro e Moreira (2018, p. 17) "o caminho que conduz à hermenêutica do sentido passa, necessariamente, pela identificação dos procedimentos que cada texto, de forma única e particular, possui".

Logo, as concepções de coerência que vão nesse sentido podem efetivamente ser consideradas como relativas à coerência no nível individual da linguagem, sobretudo, porque os autores defendem ser a coerência um princípio de interpretabilidade.

A coerência está diretamente ligada à possibilidade de se estabelecer um sentido para o texto, ou seja, ela é o que faz com que o texto faça sentido para os usuários, devendo, portanto, ser entendida como um princípio de interpretabilidade, ligada à inteligibilidade do texto numa situação de comunicação e à capacidade que o receptor tem para calcular o sentido deste texto (KOCH, TRAVAGLIA, 1989, p. 21).

Ainda que não se possa levar ao extremo a influência da subjetividade na construção da coerência, tais autores relacionam a coerência à inteligibilidade do texto na situação comunicativa e à capacidade do interlocutor em calcular sentidos para o texto. Num paralelo com Coseriu, essa capacidade mencionada por Koch e Travaglia (1989) corresponde à capacidade expressiva, própria do nível individual; o contexto, por sua vez, corresponde à noção coseriana de entornos, que são os instrumentos circunstanciais da atividade linguística. Nessa direção, seguem outras percepções de coerência, como a de Cavalcante (2017, p. 31): "na verdade, a coerência não está no texto em si; não nos é possível apontá-la, destacá-la ou sublinhá-la". O sentido pode ser objetivado, mas não apontado; apenas podemos apontar ou destacar onde e de que forma atuam os procedimentos textuais para sua construção. 
Cabe, entretanto, salientar que, estando a coerência relacionada à construção de sentidos, e esses, por sua vez, sendo "o conjunto das funções textuais, do que se entende no texto" (COSERIU, 2007, p. 152), existe, de fato, a possibilidade de que, assim como se produz um ato linguístico incongruente ou incorreto, ocorram atos linguísticos inadequados, decorrentes de um problema relativo ao saber expressivo. Algo nesse sentido, verifica-se no slogan lançado pela equipe de comunicação do ex-presidente interino Michel Temer, que foi amplamente comentado à época e acerca do qual trata uma notícia do jornal Folha de São Paulo, reproduzida em (02).

(02) Slogan 'O Brasil voltou, 20 anos em 2' implora para ser interpretado como ato falho: problema é que 'voltar' tem carga semântica de retroceder, retornar ao passado

A nova trapalhada de comunicação do governo Temer é tão perfeita que implora para ser interpretada não como tropeço banal, fruto de incompetência ou desatenção, mas como ato falho.

O ato falho é uma categoria psicanalítica de deslize, sobretudo verbal, descrita por Sigmund Freud. Sendo, em tese, a manifestação involuntária de algum desejo reprimido, o ato falho se caracteriza por revelar uma verdade oculta sobre quem o comete.

Não é possível afirmar que o governo Temer deseje, no fundo, confessar ao país de forma suicida um pacto com o retrocesso. No entanto, a frase "O Brasil voltou, 20 anos em 2 " sugere exatamente isso.

Fonte: https://www1.folha.uol.com.br/poder/2018/05/slogan-o-brasil-voltou-20-anosem-2-implora-para-ser-interpretado-como-ato-falho.shtml. Acesso em 15.jan.2020.

O slogan em questão, que se refere aos dois anos de mandato provisório de Temer, apresenta um problema quanto à função expressiva da forma verbal "voltou". O sentido que se pretendia (voltar como ressurgir) foi abafado pela possibilidade de se construir para esse termo, diante do contexto em questão (de um governo de baixa popularidade e alvo de muitas críticas), o sentido de voltar como regredir. Fica evidenciada uma inadequação na tentativa de exercer o saber expressivo. Podemos afirmar que, do ponto de vista da produção do texto, há um problema (uma inadequação) no nível individual da linguagem. Já do ponto de vista da recepção, a construção do sentido não pretendido adequação nos termos contextuais dos leitores.

Tendo em vista essa dinâmica, consideramos que o julgamento que guia a coerência nesse nível é a adequação do sentido ao contexto e ao indivíduo. Efetivamente, "uma vez construído $u m$ - e não $o$ - sentido, adequado ao contexto, às imagens recíprocas dos parceiros de comunicação, ao tipo de atividade em curso, a manifestação verbal será considerada coerente pelos interactantes" (KOCH, 2009, p. 30, grifo da autora).

A noção de adequação se alinha às características da coerência no nível individual da linguagem, posto que não há um sentido estabelecido no texto, mas uma multiplicidade de sentidos que se constroem a partir do texto. Não cabe, então, no caso, falar em correção ou congruência, porque o sentido está além da fixidez das regras gerais do pensar, do conhecimento das coisas e das regras de construção linguística próprias de uma língua.

No ensejo dessa discussão, torna-se relevante ressaltar o princípio de determinação progressiva da teoria coseriana. Esse princípio prevê que tanto as regras linguísticas do nível histórico podem ficar em suspensão em um texto em decorrência de uma motivação textual, como as regras do nível universal também podem ser suspensas em favor do nível individual. Em outras palavras, o nível individual, dada sua complexidade de inserção, como ato 
linguístico concreto, na interação, pode suspender as regras dos demais níveis com vistas ao estabelecimento do sentido.

Esse princípio também se aplica à relação entre a coerência no nível universal, a coerência no nível histórico e a coerência no nível individual da linguagem. A congruência e a correção podem ser suspensas em função da adequação. Consideremos dois trechos de um poema de Barros em (03) e (04).

No Tratado das Grandezas do Ínfimo estava escrito:

Poesia é quando a tarde está competente para dálias.

É quando

Ao lado de um pardal o dia dorme antes.

Quando o homem faz sua primeira lagartixa.

É quando um trevo assume a noite

E um sapo engole as auroras.

Fonte: (BARROS, 1993).

Nesse trecho, algumas afirmações podem contrariar o conhecimento geral das coisas. Isso ocorre, por exemplo, ao se dizer que "um sapo engole as auroras". Sabe-se que existem algumas possibilidades para o verbo "engolir" em relação a sapos, de forma que moscas ou aranhas podem ser alvo dessa ação, ao passo que auroras não. Todavia, nesse caso, suspendese a congruência sem prejuízos, posto que a intencionalidade envolvida no ato linguístico em questão supre à não subordinação ao conhecimento das coisas. No fazer poético de Manoel de Barros, o autor explicita a intenção de desaprender o funcionamento natural dos elementos do mundo. Dessa forma, o sentido se cria por vias das particularidades de um mundo textual admitido, que não corresponde às mesmas configurações esperadas para o mundo real. Essa intenção é facilmente percebida em (04).

(04)

No descomeço era o verbo.

Só depois é que veio o delírio do verbo.

O elírio do verbo estava no começo, lá onde a

criança diz: Eu escuto a cor dos passarinhos.

A criança não sabe que o verbo escutar não funciona

para cor, mas para som.

Então se a criança muda a função de um verbo, ele

delira.

E pois.

Em poesia que é voz de poeta, que é a voz de fazer nascimentos -

O verbo tem que pegar delírio.

Fonte: (BARROS, 1993).

A intenção da construção "pegar delírio" representa a finalidade de construir sentidos pela não subordinação ao conhecimento convencional do mundo real. Diante disso, os textos de Barros (1993) não podem ser tidos como incongruentes, mesmo no nível universal, tendo em vista que ocorre a suspensão desse nível pelo princípio da determinação progressiva. 


\section{CONCLUSÃO}

Os estudos linguísticos atuais apresentam diferentes conceitos de coerência, com noções diversas sendo conjugadas a perspectivas variadas de aproximação desse fenômeno. Neste trabalho, deslindamos de que modo o agrupamento desses conhecimentos pode ser empreendido, de tal forma que se distingam as características e os fatos relativos à coerência de acordo com o nível da linguagem em que ela se encontra, seguindo a teoria de Eugenio Coseriu.

Abordando como se dá o tratamento da coerência em cada um desses níveis, foi possível esclarecer que, para cada nível da linguagem, há uma concepção de coerência que a ele se alinha. Desse modo, a coerência no nível universal é um julgamento de alinhamento de um ato linguístico aos princípios gerais do falar e ao conhecimento das coisas, sendo ela relativa à rede de relações conceituais do falar; no nível histórico, a coerência é uma propriedade linguística, a qual é estabelecida pelos dispositivos de cada língua de forma própria; já no nível individual, a coerência é um conteúdo textual, isto é, o sentido que emerge na interação entre interlocutores e texto.

Entendemos também que a percepção da coerência de acordo com os três níveis da linguagem permite conceber que: a) no nível universal, a coerência mobiliza princípios; b) no nível histórico, a coerência dispõe de mecanismos próprios de uma língua; c) no nível individual, a coerência mobiliza procedimentos textuais. Essas distinções teóricas contribuem para um outro entendimento da complexidade de aspectos concernentes à coerência: trata-se de um arquifenômeno que se realiza e funciona simultaneamente de forma tripartida de acordo com os três níveis da linguagem. Esse entendimento propicia que os diferentes aspectos sejam investigados levando em consideração as particularidades nos níveis da linguagem a que correspondem.

Admitimos ainda as muitas outras possibilidades de desdobramento deste trabalho e, nesse ensejo, asseveramos a necessidade de que essa discussão seja otimizada e incrementada. Dessa maneira, a compreensão da coerência como um arquifenômeno poderá render frutos mais abundantes e eficazes para os estudos da linguagem.

\section{Referências Bibliográficas}

BARROS, Manoel de. O livro das ignorãças. 3 ed. Rio de Janeiro: Civilização Brasileira, 1993.

BEAUGRANDE, Robert-Alain de; DRESSLER, Wolfgang Ulrich. Introducción a la Lingüistica del Texto. Barcelona: Ariel, S. A, 1997.

BELLERT, Irene. On a condition of the coherence of texts. Semiótica, v.2, 1970, p. 335-63

BERNÁRDEZ, Enrique. Introducción a la Lingüistica del Texto. Espasa-calpe, S. A: Madrid, 1982.

p. $7-28$

El texto en el proceso comunicativo. Revista de Investigación Lingüística, v.6, n.2, 2003, Os sentidos do texto. São Paulo: Contexto, 2017.

CAVALCANTE, Mônica Magalhães. Os sentidos do texto. São Paulo: Contexto, 2017.

CHAROLLES, Michel. Introduction aux problèmes de la cohérence textuelle. Langue Française, 38, 1978, p. 7-42 
COSERIU, Eugenio. Determinación y entorno. Dos problemas de una lingüística del hablar. Romanistisches Jabrbuch 7, 1955, p. 24-54

Fundamentos y tareas de la Linguística Integral. Actas, II Congreso Nacional de Lingüística. San Juan (Argentina): Universidad Nacional de San Juan, vol. I, 1984, p. 37-53 O homem e sua linguagem. Rio de Janeiro: Presença, Coleção linguagem, 1987. . Competencia lingüistica. Madrid: Gredos, 1992.

Lingüistica del texto: Introducción a la hermenéutica del sentido. Edición de Óscar Loureda Lamas. Madri: Arco Libros, 2007.

JANSEN, Heidi. Objeto nulo no português: observações sobre a sua problemática. Trykk: Reprosentralen, Universitetet i Oslo, 2016.

Eugênio Coseriu en Montevideo: reconstrucción de una época. Revista de la Academia Nacional de Letras, n. 13, 2017, 7-23.

KOCH, Ingedore Grunfeld Villaça; TRAVAGLIA, Luiz Carlos. A Coerência Textual. São Paulo: Contexto, 1989.

$\mathrm{KOCH}$, Ingedore Grunfeld Villaça. O texto e a construção dos sentidos. São Paulo: Contexto, 2009.

MARCUSCHI, Luís Antônio. Linguística de texto: o que é e como se far: São Paulo: Parábola Editorial, 2012.

OLIVEIRA, Jéssica Santos. A coerência na perspectiva da teoria da linguagem de Eugenio Coseriu. Dissertação (Mestrado em Estudos da Linguagem), Programa de Pós-Graduação em Estudos da Linguagem-UFRN, Natal, 2020, 103 p.

PINHEIRO, Clemilton Lopes; MOREIRA, Juzelly Fernandes Barreto. Uma Proposta de Concepção de Estilo Fundada na Linguística Textual de Eugênio Coseriu. Revista da Anpoll, v.1, n.45, p. 248-262, 2018. 